\title{
Plants Respond to Pathogen Infection by Enhancing the Antifungal Gene Expression of Root-Associated Bacteria
}

\author{
Alexandre Jousset, ${ }^{1}$ Laurène Rochat, ${ }^{2}$ Arnaud Lanoue, ${ }^{3}$ Michael Bonkowski, ${ }^{4}$ Christoph Keel, ${ }^{2}$ and \\ Stefan Scheu ${ }^{1}$ \\ ${ }^{1}$ Georg-August-University Göttingen, J.F. Blumenbach Institute of Zoology and Anthropology, Berliner Str. 28, 37073 Göttingen, \\ Germany; ${ }^{2}$ Université de Lausanne, Département de Microbiologie Fondamentale, 1015 Lausanne, Switzerland; ${ }^{3}$ Université \\ François Rabelais de Tours. EA 2106 Plant Biotechnology and Biomolecules, 31 Avenue Monge, 37200 Tours, France; \\ ${ }^{4}$ University of Cologne, Institute of Zoology, Terrestrial Ecology and Rhizosphere Research, Zülpicher Straße 47 b, \\ 50674 Köln, Germany
}

Submitted 14 September 2010. Accepted 8 November 2010.

\begin{abstract}
Plant health and fitness widely depend on interactions with soil microorganisms. Some bacteria such as pseudomonads can inhibit pathogens by producing antibiotics, and controlling these bacteria could help improve plant fitness. In the present study, we tested whether plants induce changes in the antifungal activity of root-associated bacteria as a response to root pathogens. We grew barley plants in a split-root system with one side of the root system challenged by the pathogen Pythium ultimum and the other side inoculated with the biocontrol strain Pseudomonas fluorescens CHA0. We used reporter genes to follow the expression of ribosomal RNA indicative of the metabolic state and of the gene phlA, required for production of 2,4-diacetylphloroglucinol, a key component of antifungal activity. Infection increased the expression of the antifungal gene phlA. No contact with the pathogen was required, indicating that barley influenced gene expression by the bacteria in a systemic way. This effect relied on increased exudation of diffusible molecules increasing $p h l A$ expression, suggesting that communication with rhizosphere bacteria is part of the pathogen response of plants. Tripartite interactions among plants, pathogens, and bacteria appear as a novel determinant of plant response to root pathogens.
\end{abstract}

Plant roots interact with a multitude of beneficial and antagonistic microorganisms which significantly affect plant fitness (van der Heijden et al. 2008). Plants allocate a considerable fraction of their assimilates to the root system and exude large amounts of mono- and polysaccharides, organic acids, phenolic compounds, amino acids, and proteins (Bais et al. 2006). These exudates function as resources selecting and fueling a specific bacterial community (Mazzola 2002). In return, symbiotic rhizosphere microorganisms provide services to the plant, including protection against fungal pathogens by producing antibiotics and eliciting plant defense (Compant et al. 2005).

A. Jousset and L. Rochat contributed equally to the work.

Corresponding author: A. Jousset;

Telephone: +49551395468; E-mail: ajousse@gwdg.de

* The $\boldsymbol{e}$-Xtra logo stands for "electronic extra" and indicates a supplementary figure is published online.
Plants adjust the quantity and composition of exudates in response to root pathogens and symbionts, bacterial products, and nutrient availability (Paterson et al. 2006; Phillips et al. 2004); and exudate composition modifies the gene expression pattern of root-associated bacteria (Mark et al. 2005). This suggests that plants actively interact with these bacteria (Badri and Vivanco 2009), and we hypothesized that plants can stimulate the production of antifungal compounds of rhizosphere bacteria in response to the presence of pathogens. We investigated this tripartite interaction between plants, pathogens, and antagonistic bacteria in a split-root system with barley. One side of the root system was infected with the oomycete Pythium ultimum, a pathogen causing damping-off disease (Martin and Loper 1999). The other side was inoculated with the biocontrol bacterium Pseudomonas fluorescens CHA0, an efficient rhizosphere colonizer which protects crop plants against pathogenic fungi by producing antifungal compounds (Haas and Keel 2003; Voisard et al. 1994). Preventing direct contact between biocontrol bacteria and fungal pathogen, the split-root system allowed investigating pathogen-induced but plant-mediated effects on bacterial gene expression. We used reporter fusions to follow in situ the expression pattern of the ribosomal RNA operon $r r n B P 1$, indicating the bacterial metabolic state (Ramos et al. 2000), and the antifungal gene phlA, involved in the synthesis of 2,4-diacetylphloroglucinol (DAPG) (Bangera and Thomashow 1999; Schnider-Keel et al. 2000). DAPG is a major biocontrol toxin of $P$. fluorescens $\mathrm{CHA} 0$ and strongly inhibits Pythium spp. growth (de Souza et al. 2003). In a separate experiment, we screened root exudates of noninfected and infected barley plants and explored potential signal molecules involved in the communication between plants and biocontrol pseudomonads. Using high-performance liquid chromatography (HPLC), we analyzed the changes in exudation patterns after infection and confirmed the potential of the candidate signal molecules to elicit in vitro the expression of antifungal genes by $P$. fluorescens.

\section{RESULTS}

Effect of Pythium and Pseudomonas spp. on plant growth.

Plant fresh weight at harvest was $112.9 \pm 6.2 \mathrm{mg}$ (mean \pm standard error). Infection by Pythium ultimum reduced plant biomass by $30 \%$ in noninoculated plants $\left(\mathrm{F}_{1,14}=26.6, P=\right.$ $0.001)$ but had no effect on plants inoculated with $P$. fluorescens 
$\left(\mathrm{F}_{1,14}=0.1, P=0.748\right)$. Infection affected neither the shoot-toroot ratio of barley plants $\left(\mathrm{F}_{1,14}=1.26, P=0.280\right)$ nor the biomass of roots of the two root halves $\left(\mathrm{F}_{1,14}=0.30, P=\right.$ 0.590), suggesting that pathogen infection did not result in preferential allocation of plant resources toward the uninfected root half.

\section{Plant impact on bacterial metabolism.}

On average, roots were colonized by bacteria at $5.28 \pm 1.1$ $10^{7} \mathrm{~g}^{-1}$ of root. The colonization was not significantly affected by infection with Pythium ultimum $\left(\mathrm{F}_{1,25}<0.1, P=0.980\right)$, and bacterial basal activity (rRNA expression) was not influenced by infection $\left(\mathrm{F}_{1,25}<0.1, P=0.93\right)$. Pythium infection, however, modified the gene expression pattern of $P$. fluorescens. In control plants, the expression of phlA in P. fluorescens was negatively correlated with the expression of the ribosomal operon $r r n B P 1(r=-0.75, P=0.001)$, suggesting a competition between bacterial investment in growth versus investment in the production of antibiotics. In contrast, gene expression in bacteria colonizing infected plants was reversed $\left(\mathrm{F}_{1,25}=20.1\right.$, $P<0.001$ for treatment-rRNA $r r n B P 1$ interaction) (Fig. 1). In infected plants, the expression of the two bacterial genes was positively correlated $(r=0.62, P=0.016)$, indicating changes in bacterial metabolism following pathogen infection of the distant root half.

The relative expression of phlA increased parallel to root biomass in noninfected plants $\left(\mathrm{F}_{1,25}=12.3, P=0.004\right)$ (Fig. 2), suggesting that larger plants supported a higher antifungal activity by rhizosphere bacteria. However, the expression of phlA was $18 \%$ higher in infected plants $\left(\mathrm{F}_{1,25}=9.4, P=0.004\right)$, and the ratio between relative phlA expression and root biomass of infected plants increased 10-fold compared with control plants $\left(\mathrm{F}_{1,12}=8.4, P=0.013\right.$ for root-treatment interaction) (Fig. 2$)$.

\section{Changes in root exudation after Pythium infection.}

Vanillic, fumaric, and $p$-coumaric acids were detected in extracts of root exudates. The infection by Pythium ultimum modified the exudation of these three compounds $\left(\mathrm{F}_{3,18}=4.1, P=\right.$ 0.029 for infection-root side interaction). Exudation of vanillic, $p$-coumaric, and fumaric acids on the local (infected) side was not affected by Pythium ultimum (Fig. 3), whereas their exudation on the systemic side increased by factors of 5.1, 4.0, and

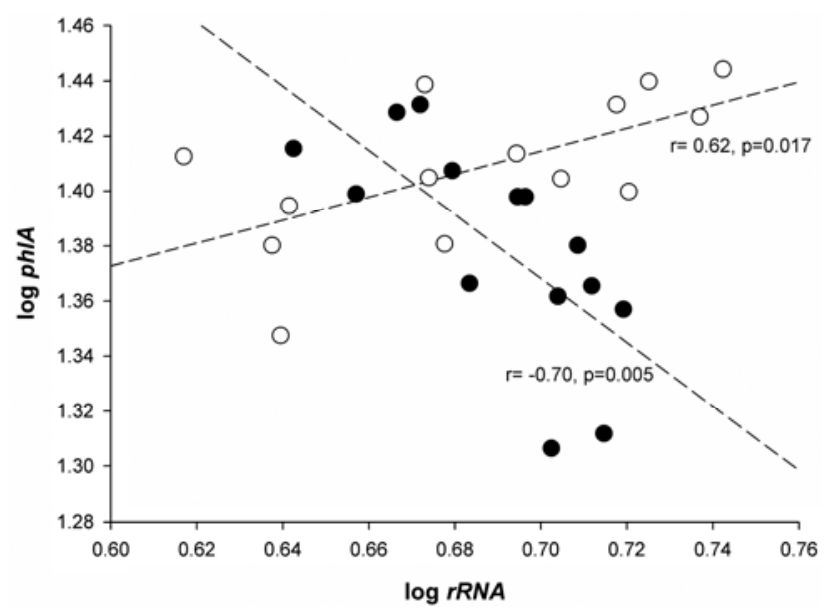

Fig. 1. Relationship between the expression of the rRNA rrnBPl and phlA genes in Pseudomonas fluorescens CHA0 on roots of uninfected plants (closed symbols) and plants infected by Pythium ultimum (open symbols) in a split-root experiment where one side of the root system was inoculated with Pythium ultimum (or left uninoculated) and the other side with $P$. fluorescens. Dashed lines show the respective regression lines for the two treatments.
2.9, respectively. Moreover, in infected plants, the exudation increased with the size of the root system $\left(\mathrm{F}_{3,18}=3.34, P=\right.$ 0.037 for infection-root side-root weight interaction).

No inhibitory effects of the tested compounds on the growth of Pythium ultimum could be detected even at elevated concentrations $(1 \mathrm{mM})$, suggesting that they do not act as antibiotic against this pathogen.

\section{In vitro effects of root exudates on phlA expression.}

All tested compounds increased the expression of phlA; the effect depended on the concentration of the compounds and could be well modeled with Michaelis-Menten kinetics $(P<$ 0.001 for all tested compounds) (Fig. 4). However, the induction of $p h l A-g f p$ expression differed between the compounds. Half maximal induction was achieved at $2.5,5.4$, and $37.2 \mu \mathrm{M}$ for vanillic, fumaric, and $p$-coumaric acids, respectively, showing that phlA gene expression is most sensitive to vanillic acid.

\section{DISCUSSION}

We present a new tripartite interaction among plants, root pathogens, and biocontrol rhizosphere bacteria. As indicated by changes in phlA expression, plants responded to pathogen infection by stimulating the activity of antifungal genes of associated rhizobacteria. Because expression levels of phlA are directly correlated with DAPG production (Baehler et al. 2005), the observed induction of phlA gene expression suggests an increased antifungal activity of the bacteria. Remarkably, no contact with root pathogens was required for this induction, suggesting that signaling from the pathogen to the bacteria was mediated via systemic signaling of the plant. In bacteria colonizing uninfected plants, the expression of phlA and $r r n B P 1$ was negatively correlated, suggesting a trade-off between the investment of resources into primary metabolism and into the production of antibiotics. These observations

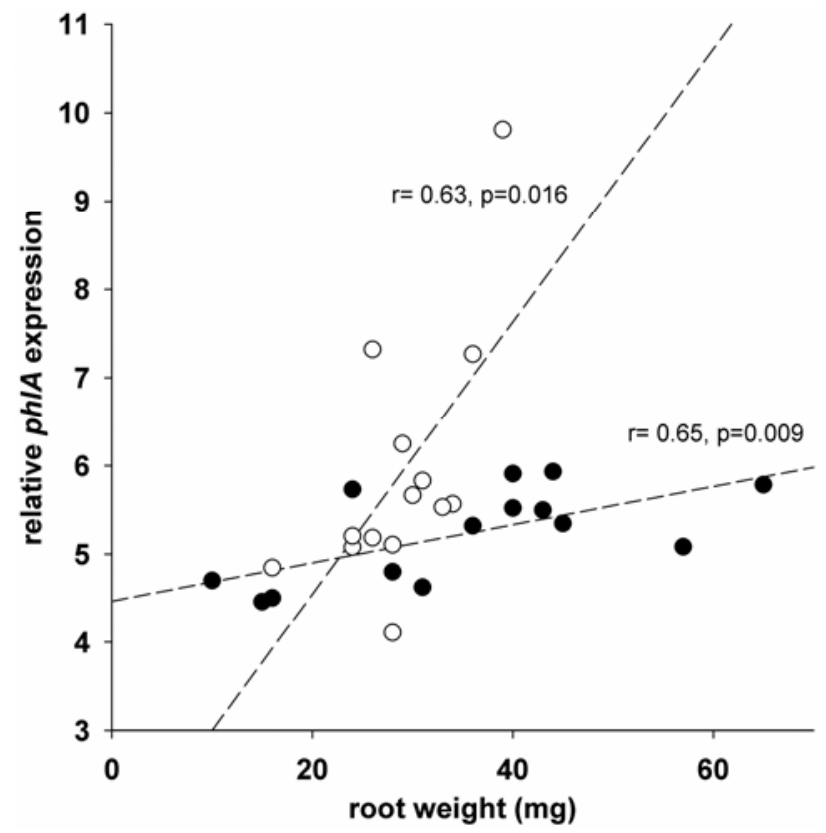

Fig. 2. Variation in the expression of the phlA gene of Pseudomonas fluorescens $\mathrm{CHA} 0$ with root biomass on roots of uninfected plants (closed symbols) and plants infected by Pythium ultimum (open symbols) in a split-root experiment where one side of the root system was inoculated with Pythium ultimum (or left uninoculated) and the other side with $P$. fluorescens. Dashed lines show the respective regression lines for the two treatments. phlA expression was normalized using the rRNA expression level as standard. Dashed lines show linear regressions for each treatment. 
corroborate with the assumption that rhizosphere bacteria are carbon limited (Normander et al. 1999). On the roots of infected plants, however, this relationship was inverted; the expression of the phlA gene was positively correlated with that of $r r n B P 1$. This suggests that bacteria were not only more active but also invested these resources into the production of antifungal compounds. This is in agreement with the observations of Phillips and associates (2004) that plants increase root exudation in response to antifungal metabolites such as DAPG, which results in a feedback loop improving biocontrol of fungal pathogens by rhizobacteria. Infected roots and roots inoculated with $P$. fluorescens CHA0 were physically separated; therefore, the results demonstrate that the switch
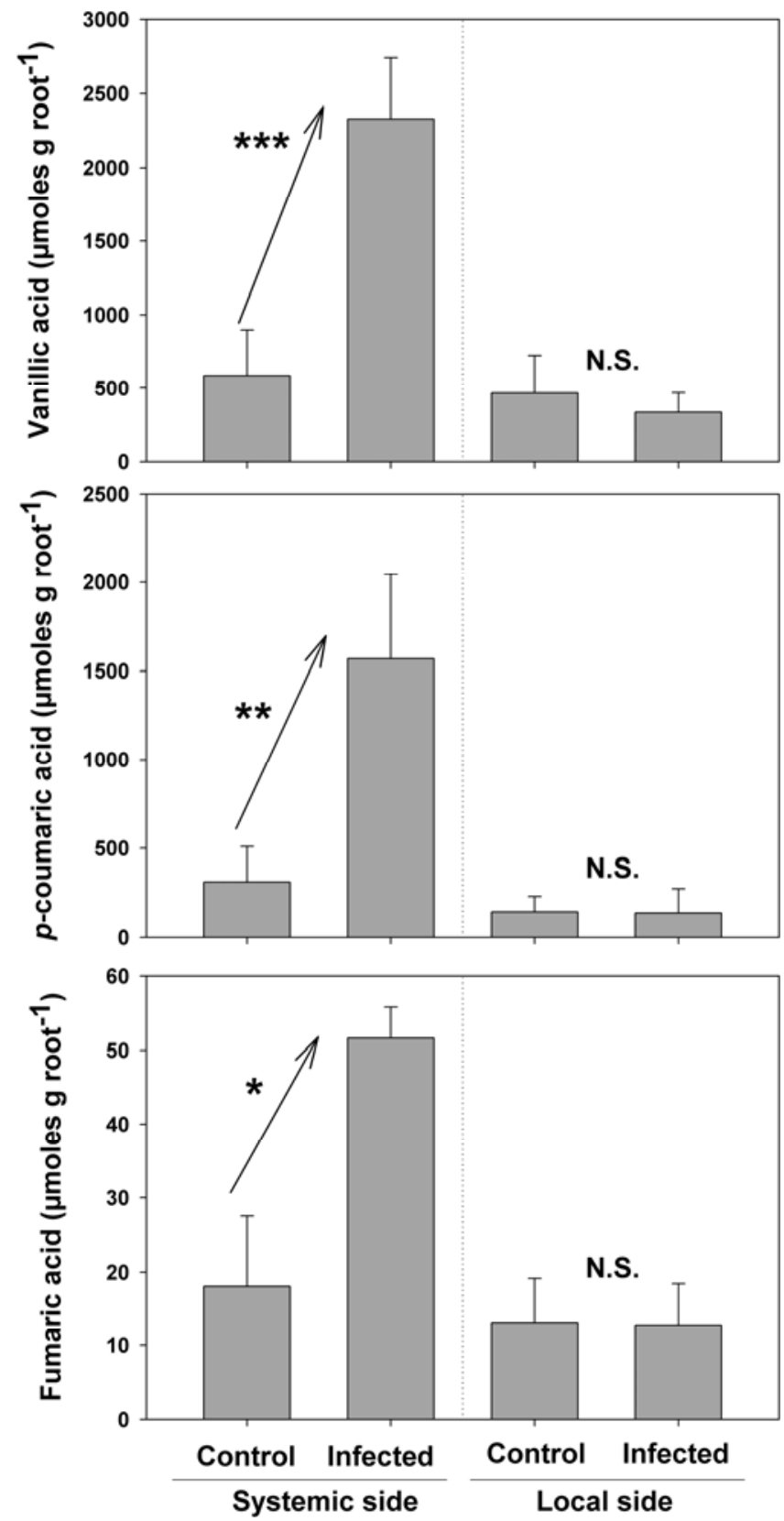

Fig. 3. Induction of the exudation of vanillic, p-coumaric, and fumaric acid by barley plants grown after infection by Pythium ultimum in splitroot systems. Exudation was measured in infected (local side) and uninfected roots halves (systemic side) in healthy (control) and infested plants (infected). Exudation is expressed in micromoles per gram of root dry weight. Asterisks indicate differences between selected treatments as indicated by Tukey's honestly significant difference test (N.S., nonsignificant; $*$ and $* *$ indicate $P<0.05$ and 0.01 , respectively). in bacterial gene expression was induced via plant signaling. These results contrast previous observations that infection of plant leaves by pathogens (Botrytis cinerea) results in downregulation of the expression of antifungal genes in $P$. fluorescens in the rhizosphere (de Werra et al. 2008). Pathogen attack can induce changes in exudation (Bezemer and van Dam 2005), and plant response may differ for aboveground and below-ground pathogens.

Root biomass also played an important role in the strength of the interaction between rhizosphere bacteria and the fungal plant pathogen. The expression of the phlA gene was positively correlated with root biomass, and pathogen infection strengthened this relationship. In barley, exudation is negatively correlated with root size (Liljeroth et al. 1990), which is likely to affect the interaction between plants and rhizosphere bacteria.
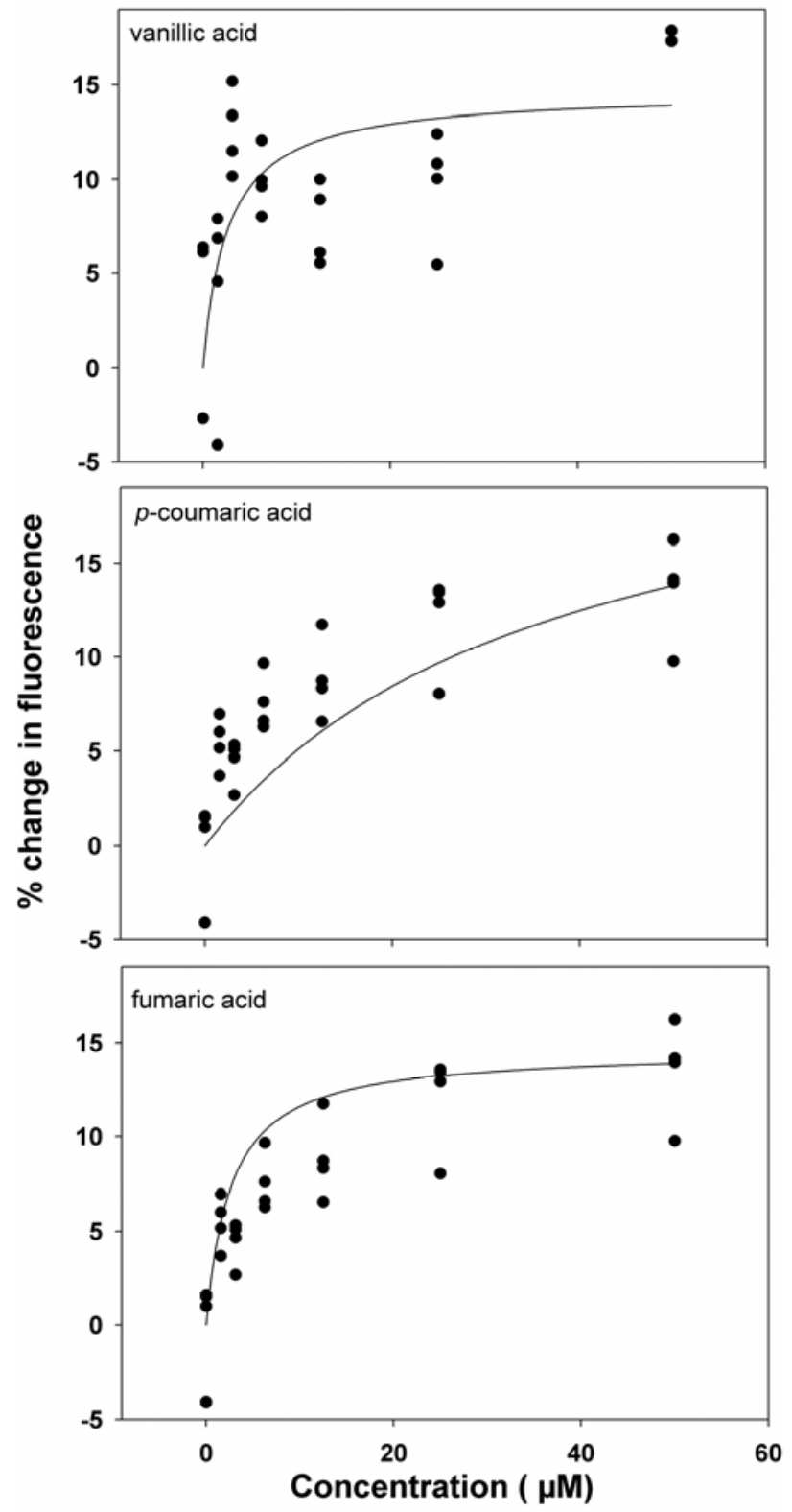

Fig. 4. Effect of vanillic, p-coumaric, and fumaric acid on the expression of phlA in Pseudomonas fluorescens CHA0 grown in minimal ammoniumglucose medium without antibiotics amended with glucose at $4 \mathrm{~g} \mathrm{liter}^{-1}$ as sole carbon source (OS-Glc). Gene activity was measured as green fluorescence (relative fluorescence) in strain CHA0 carrying the phlAgfp[AAV] reporter fusion. Fluorescence was measured after $6 \mathrm{~h}$ and normalized to the control treatment (methanol). The regression curve is based on Michaelis-Menten fitting. 
Plant root exudates function as belowground signaling molecules shaping rhizosphere microbial populations (Badri et al. 2009), and exudation is a dynamic process adjusted according to the needs of the plant (Paterson et al. 2006). Both beneficial rhizosphere bacteria and pathogens affect root exudation (Kamilova et al. 2006; Phillips et al. 2004). Root infection results in marked changes in the exudation of phenolic and organic acids (Lanoue et al. 2010; Wurst et al. 2009), and our results show that these changes may form the base of a tripartite interaction among plants, fungal pathogens, and rhizosphere bacteria. Indeed, vanillic and fumaric acid, signal compounds which changed markedly in concentration after pathogen infection, induced the expression of phlA even at very low concentration. This suggests that small changes in exudation may result in increased expression of antifungal genes by $P$. fluorescens.

Rhizosphere bacteria and fungal root pathogens are linked via plant carbon resources exuded by roots (Notz et al. 2002; Paterson et al. 2006). Interestingly, neither the expression of rrnBP 1 nor the colonization of roots by $P$. fluorescens was influenced by the infection of roots with Pythium ultimum, suggesting that, in addition to resource-based linkages, the interaction between plant-associated microorganisms is modulated by plant signals affecting bacterial secondary metabolism.

Remarkably, local exudation of infected roots was little influenced by the infection with Pythium ultimum, whereas exudation of vanillic, $p$-coumaric, and fumaric acids of noninfected roots at the other compartment of the split-root system increased up to fourfold. This is surprising considering the usual increase in secondary metabolite exudation in the presence of pathogens (Bais et al. 2002; Lanoue et al. 2010). This may have been due to degradation of the studied secondary compounds by the pathogen or by reduced resource allocation by the plant to infected roots (Henkes et al. 2008). Changes in root exudation after pathogen infection mainly have been assessed at the scale of the whole root system, overlooking the spatial heterogeneity of exudation. Thus, the split-root system used in this study may help to clarify questions regarding local or systemic exudation of plant roots upon infection.

The induced exudates had no effect on the mycelium growth of Pythium ultimum. This is surprising, because vanillic and $p$ coumaric acid have been reported to inhibit fungal growth (Kim et al. 2006; Lanoue et al. 2010) and our results indicate that, in addition to toxicity, organic and phenolic acids form part of the pathogen response of plants by acting as signal molecules for symbiotic rhizobacteria. Beneficial antibiotics such as DAPG also may have phytotoxic side effects (Brazelton et al. 2008), and plants may only benefit from fostering their production in the presence of pathogens. Thus, root exudates not only participate in the control of belowground pathogens (Bais et al. 2005; Lugtenberg and Kamilova 2009) but also are involved in the interaction between plant roots and beneficial rhizobacteria.

The exudation of signal molecules by part of the roots not exposed to the fungal pathogen suggests that plant-bacteria signaling not only results from local interaction with the patho- gen (e.g., due to nutrient leakage) (Notz et al. 2001; Lanoue et al. 2010) but also is triggered systemically by pathogen infection. Plants can sense and respond to signal compounds produced by beneficial rhizosphere bacteria (Lugtenberg and Kamilova 2009), and bidirectional communication between plants and bacteria may occur. Our results indicate that this signaling allows plants to rapidly respond to fungal pathogens via systemic responses. Further analyses in gnotobiotic systems are needed to test the direction of this signaling as well as the signal cascades involved. These experiments, however, are challenging because they have to overcome the difficulties of distinguishing between plant and bacterial metabolites, and plant signal compounds transformed by rhizobacteria.

Overall, this study proposes plant interaction with beneficial rhizosphere bacteria as a new component of pathogen response. Efficient communication between plants and rootassociated bacteria may significantly increase plant fitness under pathogen pressure, and understanding the plant traits linked to this interaction may help to establish new diseaseresistant cultivars.

\section{MATERIALS AND METHODS}

Microorganisms, plasmids, and culture conditions.

Bacteria and plasmids used in this study are listed in Table 1. The strains were kept on nutrient agar plates with the corresponding antibiotics. Prior to inoculation, bacteria from a single colony were grown in liquid Luria Bertani (Sambrook and Russell 2001) at $25^{\circ} \mathrm{C}$ for $12 \mathrm{~h}$ with agitation (200 rpm). Bacterial cells from early exponential phase cultures (optical density at $600 \mathrm{~nm}\left[\mathrm{OD}_{600}\right]=0.3$ ) were harvested by centrifugation $\left(4,600 \mathrm{rpm}, 4^{\circ} \mathrm{C}, 10 \mathrm{~min}\right)$, washed in $0.9 \% \mathrm{NaCl}$, and resuspended in Neff's modified amoeba saline (AS) (Page 1988). The metabolic state of the bacteria was estimated with a reporter miniTn7-gfp chromosomal insert placed under the control of the growth-rate-dependent promoter $\mathrm{P}_{\text {rrnBP1 }}$ (Lambertsen et al. 2004). To follow the expression of the antifungal gene phlA in the rhizosphere, a mcherry-based reporter fusion placed under the control of the phlA promoter on plasmid pME9012 was used (Table 1). A reporter fusion based on an unstable green fluorescent protein (GFP) variant carried by plasmid pME7102 (Baehler et al. 2005) was used for monitoring phlA expression in vitro. These two reporter fusions have been shown to reflect the actual phlA expression level by the bacteria (Baehler et al. 2005), and the expression of the phl operon is itself correlated with the rate of DAPG production by $P$. fluorescens CHA0 (Notz et al. 2001). Standard methods were used for plasmid extraction and transformation of bacteria (Sambrook and Russell 2001) and for Tn7-based transposition (Schnider-Keel et al. 2000).

Pythium ultimum was kept routinely on $20 \%$ V8 agar (V8 at $200 \mathrm{ml} \mathrm{liter}^{-1}, \mathrm{CaCO}_{3}$ at $10 \mathrm{~g} \mathrm{liter}^{-1}$, and agar at $\left.20 \mathrm{~g} \mathrm{liter}^{-1}\right)$. An actively growing mycelium inoculum was prepared on autoclaved millet seed as described elsewhere (Notz et al. 2001). Plates were incubated at room temperature in the dark for 7 days and regularly mixed to ensure homogenous distribution.

Table 1. Strains and plasmids used in this study

\begin{tabular}{|c|c|c|}
\hline Strain or plasmid & Genotype and phenotype ${ }^{a}$ & Reference \\
\hline \multicolumn{3}{|c|}{ Pseudomonas fluorescens } \\
\hline CHA0 & Wild type, biocontrol strain & Voisard et al. 1994 \\
\hline CHA0- $\mathrm{P}_{\text {rrnB }}-g f p$ & CHA0::att Tn7-P $\mathrm{P}_{\mathrm{rnB} \mathrm{P}^{-}}-g f p-\mathrm{a} ; \mathrm{Gm}^{\mathrm{r}}$ & This study \\
\hline \multicolumn{3}{|l|}{ Plasmids } \\
\hline Psm1973 & $\operatorname{miniTn} 7(\mathrm{Gm}) \mathrm{P}_{\text {rrnB P1}}-g f p-\mathrm{a} ; \mathrm{Gm}^{\mathrm{r}}$ & Lambertsen et al. 2004 \\
\hline pME7102 & phlA-gfp $[A A V]$ transcriptional fusion; reporter for DAPG biosynthetic gene expression; $\mathrm{Tc}^{\mathrm{r}}$ & Baehler et al. 2005 \\
\hline pME9012 & phlA-mcherry transcriptional fusion; reporter for DAPG biosynthetic gene expression; $\mathrm{Km}^{\mathrm{r}}$ & Rochat et al. 2010 \\
\hline
\end{tabular}

${ }^{\mathrm{a}} \mathrm{Gm}^{\mathrm{r}}, \mathrm{Km}^{\mathrm{r}}$, and $\mathrm{Tc}^{\mathrm{r}}$ indicate gentamicin, kanamycin, and tetracycline resistance, respectively. DAPG = 2,4-diacetylphloroglucinol. 


\section{Plants.}

Seed of barley (Hordeum vulgare cv. Barke) were dehusked by immersion in $50 \% \mathrm{H}_{2} \mathrm{SO}_{4}$ with agitation for $90 \mathrm{~min}$ and washed twice in $0.5 \mathrm{M} \mathrm{NaHCO}_{3}$ solution to neutralize the acid. Seed were sterilized by soaking in $70 \%$ ethanol for $2 \mathrm{~min}$ and $2 \% \mathrm{AgNO}_{3}$ for $30 \mathrm{~min}$ with agitation. Silver residues were removed by five successive washing cycles in $0.9 \% \mathrm{NaCl}$ and distilled water of $10 \mathrm{~min}$ each. The seed were germinated individually on water agar $\left(8 \mathrm{~g} \mathrm{liter}^{-1}\right)$. After 6 days, the plantlets were checked for contamination, transferred to the split-root microcosm (discussed below), and inoculated according to the treatments.

\section{Microcosm construction and inoculation.}

The split-root microcosms used for reporter fusion assays were constructed from 250-by-160-by-15-mm polycarbonate plates (Supplementary Fig. S1). One plant seedling was placed in each microcosm and the roots were equally distributed into the two split-root chambers. Prior to establishment of the seedlings, the microcosms were autoclaved and each chamber half (100 by 150 by $5 \mathrm{~mm}$ ) was filled with $15 \mathrm{ml}$ of sterile $1 / 5$ Long Ashton nutrient solution (Hewitt 1966) in 2\% agar. Sterile seedlings were added aseptically after cooling of the microcosms and inoculated as described below. The microcosms were covered with a 6-mm-thick polycarbonate lid fixed tightly with paper clamps. The opening of the microcosms around the shoot base was sealed with autoclaved Terostat VII sealing mass (Henkel, Düsseldorf, Germany). Microcosms for HPLC analysis of root exudates were built of two 12-ml glass tubes with polyethylene lid (Neolab, Heidelberg, Germany). The tubes were washed twice in ethyl acetate, autoclaved, glued together, and filled with $10 \mathrm{ml}$ of $\mathrm{HPLC} \mathrm{H}_{2} \mathrm{O}$ (Roth, Karlsruhe, Germany).

Four treatments were set up: noninoculated, Pythium ultimum, P. fluorescens, and Pythium ultimum + P. fluorescens. To avoid direct contact between the organisms, Pythium ultimum and $P$. fluorescens were always inoculated onto different halves of the split-root system (referred to as "local", in contact with the pathogen, and "systemic", the response side without pathogen). The local side of the split-root system received $500 \mathrm{mg}$ of the Pythium inoculum (discussed above) or $500 \mathrm{mg}$ of uninfected sterile millet seed as control. For reporter fusion assays, the systemic side was inoculated with $1 \mathrm{ml}$ of a $1: 1$ mixture of the two reporter strains of $P$. fluorescens $\mathrm{CHA} 0$ (CHA0- $\mathrm{P}_{\text {rrnB }}-g f p$ and CHA0/pME9012, $\mathrm{OD}_{600}=0.1$ ); in the control treatment $1 \mathrm{ml}$ of AS was added.

In the microcosms used for HPLC measurement, the local side of the root system was infected with chopped Pythium mycelium. The systemic side was left sterile. The opening was sealed with autoclaved silicon grease. Plants were grown with a 16-h light phase $\left(22^{\circ} \mathrm{C}, 500 \mu \mathrm{mol} \mathrm{s}{ }^{-1} \mathrm{~m}^{-2}\right)$ and $8 \mathrm{~h}$ of darkness $\left(18^{\circ} \mathrm{C}\right)$ at $60 \%$ relative humidity for 6 days. In all, 14 and 6 replicates were set up per treatment for the reporter assay and the HPLC measurement, respectively.

\section{Measurement of bacterial activity.}

Six days after inoculation, the microcosms were destructively sampled. Roots inoculated with $P$. fluorescens were placed in $10 \mathrm{ml}$ of cold phosphate-buffered saline buffer containing $0.8 \%$ formaldehyde, and root-associated bacteria were extracted by vigorously shaking the roots for $20 \mathrm{~min}$. Samples were kept at $4^{\circ} \mathrm{C}$ until analysis. In situ expression of the phlAmcherry and $\mathrm{P}_{\mathrm{rrnBP}}-g f p$ reporter fusions was analyzed with a FACScalibur flow cytometer (Becton and Dickinson, San Jose, CA, U.S.A.) equipped with a 15-mW air-cooled argon ion laser excitation light source $(488 \mathrm{~nm})$. GFP and mCherry fluorescence emissions were measured at 530 and $661 \mathrm{~nm}$, respec- tively, and amplified with a logarithmic gain. Forward scatter (FSC) signals were collected using a photodiode with an amplification factor of 10 , a threshold of 253, and a log gain. Side scatter signals were measured using a photomultiplier tube set at $350 \mathrm{~V}$, a threshold of 72, and a log gain.

Data were collected using CellQuest software (Becton and Dickinson) and analyzed with WinMDI 2.8 (The Scripps Research Institute FACS Core Facility webpage). Gating was done on the base of the FSC signal. Fluorescence signals were gated using the complementary single fluorescent strains as blank in order to eliminate the background fluorescence.

Bacteria colonizing the roots were counted with an inverted fluorescence microscope after staining with 4',6-diamidino-2phenylindole as described elsewhere (Normander et al. 1999).

\section{Extraction of root exudates.}

Samples of the media $(5 \mathrm{ml})$ from each of the treatments were filtered through a $0.22-\mu \mathrm{m}$ filter (Millipore, Bedford, MA, U.S.A.), acidified to $\mathrm{pH} 2$ with $1 \mathrm{~N} \mathrm{HCl}$, and extracted in $5 \mathrm{ml}$ of ethyl acetate on an orbital shaker at $300 \mathrm{rpm}$ (Bühler, Hechingen, Germany) at room temperature for $1 \mathrm{~h}$. The organic phase was evaporated under nitrogen and the residue taken up in $70 \mu \mathrm{l}$ of methanol for HPLC analyses.

\section{HPLC-diode array detection analysis.}

The HPLC apparatus consisted of a Waters system equipped with a gradient pump (Waters 600 controller; Milford, MA, U.S.A.), a cooled autosampler (Waters 717 plus), and a UVvisible photodiode array detector set (Waters 996) to acquire data from 200 to $400 \mathrm{~nm}$. Empower 2 software from Waters was used for instrument control, data acquisition, and data processing. Analyses were performed on a $3-\mu \mathrm{m}$ column (250 by $4 \mathrm{~mm}$, Multospher 120 RP18HP; CS-Service, Langerwehe, Germany) at room temperature $\left(21^{\circ} \mathrm{C}\right)$. The mobile phase consisted of aqueous phosphoric acid $(0.1 \% \mathrm{wt} / \mathrm{vol}$; eluent $\mathrm{A})$ and acetonitrile (eluent B) pumped at $0.5 \mathrm{ml} \mathrm{min}^{-1}$ into the HPLC system (Lanoue et al. 2010). The gradient started at 5\% B and increased linearly to $72 \%$ in $60 \mathrm{~min}$, followed by washing and reconditioning of the column. Wavelength detection was set at $219 \mathrm{~nm}$ for vanillic acid (retention time $[\mathrm{RT}]=30.11 \mathrm{~min}$ ), $310 \mathrm{~nm}$ for $p$ coumaric acid (RT = $35.4 \mathrm{~min}$ ), and $210 \mathrm{~nm}$ for fumaric acid $(\mathrm{RT}=9.79 \mathrm{~min})$. Wavelength detection was set at $219 \mathrm{~nm}$ for vanillic acid, $310 \mathrm{~nm}$ for $p$-coumaric acid, and 210 $\mathrm{nm}$ for fumaric acid. Compounds in extracts were identified according to their UV spectra and retention time by comparison with authentic standards.

\section{Chemicals.}

Standard compounds vanillic acid, $p$-coumaric acid, and fumaric acid were purchased from Sigma-Aldrich (St. Louis). Acetonitrile (LiChrosolv), methanol (LiChrosolv), and ethyl acetate (LiChrosolv) were obtained from Merck (Darmstadt, Germany). Ultrapure water was obtained from a Millipore Milli-Q water purification system.

\section{Effects of pure compounds on phlA expression.}

In order to assess the effect of single exudated chemicals as signal compound affecting antifungal gene expression, $P$. fluorescens CHA0 carrying pME7102 (Table 1) was grown in a minimal ammonium-glucose medium without antibiotics amended with glucose at $4 \mathrm{~g} \mathrm{liter}^{-1}$ as sole carbon source (OSGlc) (Schnider-Keel et al. 2000) in 96-well microtiter plates (Greiner Bio-one, Frickenhausen, Germany). The test compounds of p-coumaric, vanillic, and fumaric acid were dissolved in methanol and added at a final concentration of 50, 25, 12.5, $6.25,3.63$, and $1.82 \mu \mathrm{M}$ (four replicates each). Bacterial cultures $\left(200 \mu \mathrm{l}\right.$ per well) were incubated at $25^{\circ} \mathrm{C}$ with agitation 
(500 rpm). Green fluorescence (excitation at $485 \mathrm{~nm}$ and emission at $520 \mathrm{~nm}$ ) and $\mathrm{OD}_{600}$ were recorded at regular intervals with an M200 microplate reader (Tecan, Crailsheim, Germany) during $6 \mathrm{~h}$. Relative fluorescence (RFU) was expressed as the ratio between total green fluorescence value and $\mathrm{OD}_{600}$. The autofluorescence of $P$. fluorescens CHA0 was used for background correction. Methanol without test compounds was used as control. As indicated by preliminary experiments, vanillic, p-coumaric, and fumaric acids are not used as a carbon source by $P$. fluorescens $\mathrm{CHA} 0$ because the strain was unable to grow on minimal medium supplemented with $1 \mathrm{mM}$ of any of these compounds (data not shown). RFU after $6 \mathrm{~h}$ was normalized by calculating the percentage change relative to the control level. The stimulatory activity of the tested compounds as a function of their concentration was assessed with the single substrate Michaelis-Menten kinetics as described elsewhere (Kay et al. 2005) to retrieve the molecule concentration required for inducing half the maximal change in phlA expression.

\section{Statistical analysis.}

Geometrical means for FL1 (GFP) and FL3 (mCherry) signals were normalized prior to analysis. Gene expression of the bacteria was analyzed using a general linear model with a full factorial design. The model investigated the effect of infection by Pythium ultimum and of root size on the normalized phlA value and on the relationship between the expression level of rRNA and phlA. The effect of infection on the ratio between primary and secondary metabolism was determined by analyzing the expression of phlA as a function of the infection status and the expression of rRNA rrnBP1. The effect of Pythium infection on vanillic, $p$-coumaric, and fumaric acid root exudation was analyzed by two-factor analysis of variance (ANOVA) with the factors infection (Pythium or Control) and root side (local or systemic). Effects of single compounds on the expression of phlA in vitro were tested at five time points with a nested ANOVA. All statistical analyses were performed in STATISTICA 7.1 (Statsoft Inc., Tulsa, OK, U.S.A.). All experiments were repeated with similar results.

\section{ACKNOWLEDGMENTS}

We thank L. Lambertsen and S. Molin (DTU, Denmark) for providing the $P_{r r n B^{-}}$gfp reporter fusion on Psm1973. This work was funded by the fellowship program of the German Federal Foundation for the Environment (DBU) and support from the Swiss National Science Foundation (projects 3100A0-120121/1 and 3100A0-105881).

\section{LITERATURE CITED}

Badri, D. V., and Vivanco, J. M. 2009. Regulation and function of root exudates. Plant Cell Environ. 32:666-681.

Badri, D. V., Weir, T. L., van der Lelie, D., and Vivanco, J. M. 2009. Rhizosphere chemical dialogues: plant-microbe interactions. Curr. Opin. Biotechnol. 20:642-650.

Baehler, E., Bottiglieri, M., Pechy-Tarr, M., Maurhofer, M., and Keel, C. 2005. Use of green fluorescent protein-based reporters to monitor balanced production of antifungal compounds in the biocontrol agent Pseudomonas fluorescens CHA0. J. Appl. Microbiol. 99:24-38.

Bais, H. P., Walker, T. S., Schweizer, H. P., and Vivanco, J..A. 2002. Root specific elicitation and antimicrobial activity of rosmarinic acid in hairy root cultures of Ocimum basilicum. Plant Physiol. Biochem. 40:983995.

Bais, H. P., Prithiviraj, B., Jha, A. K., Ausubel, F. M., and Vivanco, J. M. 2005. Mediation of pathogen resistance by exudation of antimicrobials from roots. Nature 434:217-221.

Bais, H. P., Weir, T. L., Perry, L. G., Gilroy, S., and Vivanco, J. M. 2006. The role of root exudates in rhizosphere interactions with plants and other organisms. Annu. Rev. Plant Biol. 57:233-266.

Bangera, M. G., and Thomashow, L. S. 1999. Identification and characterization of gene cluster for synthesis of the polyketide antibiotic 2,4diacetylphloroglucinol from Pseudomonas fluorescens Q2-87. J. Bacte- riol. 181:3155-3163.

Bezemer, T. M., and van Dam, N. M. 2005. Linking aboveground and belowground interactions via induced plant defenses. Trends Ecol. Evol. 20:617-624.

Brazelton, J. N., Pfeufer, E. E., Sweat, T. A., Gardener, B. B. M., and Coenen, C. 2008. 2,4-diacetylphloroglucinol alters plant root development. Mol. Plant-Microbe Interact. 21:1349-1358.

Compant, S., Duffy, B., Nowak, J., Clement, C., and Barka, E. A. 2005. Use of plant growth-promoting bacteria for biocontrol of plant diseases: principles, mechanisms of action, and future prospects. Appl. Environ. Microbiol. 71:4951-4959.

de Souza, J. T., Arnould, C., Deulvot, C., Lemanceau, P., GianinazziPearson, V., and Raaijmakers, J. M. 2003. Effect of 2,4-diacetylphloroglucinol on Pythium: cellular responses and variation in sensitivity among propagules and species. Phytopathology 93:966-975.

de Werra, P., Baehler, E., Huser, A., Keel, C., and Maurhofer, M. 2008. Detection of plant-modulated alterations in antifungal gene expression in Pseudomonas fluorescens CHA0 on roots by flow cytometry. Appl. Environ. Microbiol. 74:1339-1349.

Haas, D., and Keel, C. 2003. Regulation of antibiotic production in rootcolonizing Pseudomonas spp. and relevance for biological control of plant disease. Annu. Rev. Phytopathol. 41:117-153.

Henkes, G. J., Thorpe, M. R., Minchin, P. E. H., Schurr, U., and Rose, U. S. R. 2008. Jasmonic acid treatment to part of the root system is consistent with simulated leaf herbivory, diverting recently assimilated carbon towards untreated roots within an hour. Plant Cell Environ. 31:1229-1236.

Hewitt, E. 1966. Sand and Water Culture Methods Used in the Study of Plant Nutrition. Commonwealth Agricultural Bureau, Farnham, U.K.

Kamilova, F., Kravchenko, L. V., Shaposhnikov, A. I., Makarova, N., and Lugtenberg, B. 2006. Effects of the tomato pathogen Fusarium oxysporum f. sp radicis-lycopersici and of the biocontrol bacterium Pseudomonas fluorescens WCS365 on the composition of organic acids and sugars in tomato root exudate. Mol. Plant-Microbe Interact. 19:1121-1126.

Kay, E., Dubuis, C., and Haas, D. 2005. Three small RNAs jointly ensure secondary metabolism and biocontrol in Pseudomonas fluorescens CHA0. Proc. Natl. Acad. Sci. U.S.A. 102:17136-17141.

Kim, J. H., Campbell, B. C., Mahoney, N., Chan, K. L., and May, G. S. 2006. Targeting antioxidative signal transduction and stress response system: control of pathogenic Aspergillus with phenolics that inhibit mitochondrial function. J. Appl. Microbiol. 101:181-189.

Lambertsen, L., Sternberg, C., and Molin, S. 2004. Mini-Tn7 transposons for site-specific tagging of bacteria with fluorescent proteins. Environ. Microbiol. 6:726-732.

Lanoue, A., Burlat, V., Henkes, G. J., Koch, I., Schurr, U., and Rose, U. S. R. 2010. De novo biosynthesis of defense root exudates in response to Fusarium attack in barley. New Phytol. 185:577-588.

Liljeroth, E., Baath, E., Mathiasson, I., and Lundborg, T. 1990. Root exudation and rhizoplane bacterial abundance of barley (Hordeum Vulgare $\mathrm{L})$ in relation to nitrogen-fertilization and root-growth. Plant Soil 127:81-89.

Lugtenberg, B., and Kamilova, F. 2009. Plant-growth-promoting rhizobacteria. Annu. Rev. Microbiol. 63:541-556.

Mark, G. L., Dow, J. M., Kiely, P. D., Higgins, H., Haynes, J., Baysse, C., Abbas, A., Foley, T., Franks, A., Morrissey, J., and O'Gara, F. 2005 Transcriptome profiling of bacterial responses to root exudates identifies genes involved in microbe-plant interactions. Proc. Natl. Acad. Sci. U.S.A. 102:17454-17459.

Martin, F. N., and Loper, J. E. 1999. Soilborne plant diseases caused by Pythium spp.: ecology, epidemiology, and prospects for biological control. Crit. Rev. Plant Sci. 18:111-181.

Mazzola, M. 2002. Mechanisms of natural soil suppressiveness to soilborne diseases. Antonie Leeuwenhoek 81:557-564.

Normander, B., Hendriksen, N. B., and Nybroe, O. 1999. Green fluorescent protein-marked Pseudomonas fluorescens: localization, viability, and activity in the natural barley rhizosphere. Appl. Environ. Microbiol. 65:4646-4651.

Notz, R., Maurhofer, M., Schnider-Keel, U., Duffy, B., Haas, D., and Defago, G. 2001. Biotic factors affecting expression of the 2,4-diacetylphloroglucinol biosynthesis gene phlA in Pseudomonas fluorescens biocontrol strain CHA0 in the rhizosphere. Phytopathology 91:873-881.

Notz, R., Maurhofer, M., Dubach, H., Haas, D., and Defago, G. 2002. Fusaric acid-producing strains of Fusarium oxysporum alter 2,4-diacetylphloroglucinol biosynthetic gene expression in Pseudomonas fluorescens $\mathrm{CHA0}$ in vitro and in the rhizosphere of wheat. Appl. Environ. Microbiol. 68:2229-2235.

Page, F. C. 1988. A New Key to Freshwater and Soil Gymnaboeae. Freshwater Biological Association, Ambleside, U.K.

Paterson, E., Sim, A., Standing, D., Dorward, M., and McDonald, A. J. 2006. Root exudation from Hordeum vulgare in response to localized nitrate supply. J. Exp. Bot. 57:2413-2420. 
Phillips, D. A., Fox, T. C., King, M. D., Bhuvaneswari, T. V., and Teuber, L. R. 2004. Microbial products trigger amino acid exudation from plant roots. Plant Physiol. 136:2887-2894.

Ramos, C., Molbak, L., and Molin, S. 2000. Bacterial activity in the rhizosphere analyzed at the single-cell level by monitoring ribosome contents and synthesis rates. Appl. Environ. Microbiol. 66:801-809.

Rochat, L., Pechy-Tarr, M., Baehler, E., Maurhofer, M., and Keel, C. 2010. Combination of fluorescent reporters for simultaneous monitoring of root colonization and antifungal gene expression by a biocontrol pseudomonad on cereals with flow cytometry. Mol. Plant-Microbe Interact. 23:949-961.

Sambrook, J., and Russell, D. 2001. Molecular Cloning: A Laboratory Manual. Cold Spring Harbor Laboratory Press, Cold Spring Harbor, NY, U.S.A.

Schnider-Keel, U., Seematter, A., Maurhofer, M., Blumer, C., Duffy, B., Gigot-Bonnefoy, C., Reimmann, C., Notz, R., Defago, G., Haas, D., and Keel, C. 2000. Autoinduction of 2,4-diacetylphloroglucinol biosynthesis in the biocontrol agent Pseudomonas fluorescens CHA0 and repression by the bacterial metabolites salicylate and pyoluteorin. J.
Bacteriol. 182:1215-1225.

van der Heijden, M. G. A., Bardgett, R. D., and van Straalen, N. M. 2008. The unseen majority: soil microbes as drivers of plant diversity and productivity in terrestrial ecosystems. Ecol. Lett. 11:296-310.

Voisard, C., Bull, C. T., Keel, C., Laville, J., Maurhofer, M., Schnider, M., Défago, G., and Haas, D. 1994. Biocontrol of root diseases by Pseudomonas fluorescens CHA0: current concepts and experimental approaches. Pages 67-89 in: Molecular Ecology of Rhizosphere Microorganisms. F. O'Gara, D. N. Dowling, B. Boesten, eds. VCH, Weinheim, Germany.

Wurst, S., van Beersum, S., Wagenaar, R., Bakx-Schotman, T., Drigo, B., Janzik, I., Lanoue, A., and van der Putten, W. H. 2009. Plant defence against nematodes is not mediated by changes in the soil microbial community. Funct. Ecol. 23:488-495.

\section{AUTHOR-RECOMMENDED INTERNET RESOURCE}

The Scripps Research Institute FACS Core Facility software webpage: facs.scripps.edu/software.html 